\title{
TANTANGAN PENDIDIK DI ERA MILLENNIAL
}

\author{
Mahyuddin Barni \\ UIN Antasari Banjarmasin \\ email: mahyuddinbarni@yahoo.co.id
}

\section{Received : 2019-04-10 ; Accepted :2019-04-30 ; Published : 2019-04-24}

\begin{abstract}
Millennial or Generation $Y$ is a group of people born after Generation $X$, namely people born in the range of 1980-2000. Now, this generation is between the ages of 17-37. There are some millennial students who have dropped out of school or graduated from universities and entered to work, but most of them are still in the school system.

The image and concept of the teacher in contemporary society is very much different from the concept of the past. The past teacher means knowledgeable, wise, and prudent. Nowadays, teachers are seen as educational functionaries who are tasked with teaching on the basis of certain scientific and academic qualifications. With this task, the teacher receives material rewards from the state or the education manager. Thus, the most important factor in the teaching profession is scientific and academic qualifications. Meanwhile, wisdom and prudence which are moral attitudes and behaviors are no longer significant. In the classical concept, moral factors are above teacher qualifications.

In general, teachers should understand the social changes that exist in the present. Teachers must not stop learning about new things. Global challenges in the current era are also different from the global challenges from the past. Whatever steps and methods carried out at school are certainly aimed at forming character and preparing quality human resources in Indonesia.

In this paper, the author will outline the challenges for teachers in the millennial era and the efforts made in dealing with these challenges. Previously the author also explained about the millennial generation, and the professionalism of teachers.
\end{abstract}

Keywords: millennial generation, millennial teacher, challenge and effort of teacher

Pendidikan berasal dari kata didik yang berarti memelihara dan memberi latihan (ajaran, pimpinan) mengenai akhlak dan kecerdasan pikiran. Pendidikan berarti proses pengubahan sikap dan tata laku seseorang atau kelompok orang dalam

\section{DOI : 10.23971/tf.v3i1.1251}

Transformatif (Journal Islamic Studies) 3 (1), Hal 99-116

Copyright (C) 2019 by Transformatif, p-ISSN 2580-7056; e-ISSN 2580-7064 
usaha mendewasakan manusia melalui upaya pengajaran dan latihan. ${ }^{1}$ "Kata pendidikan selanjutnya sering digunakan untuk menerjemahkan kata education dalam bahasa Inggris." 2

Secara istilah, ada beberapa pengertian dari para ahli pendidikan. Langeveld yang dikutip oleh Burhanuddin Salam berpendapat bahwa pendidikan adalah suatu bimbingan yang diberikan oleh orang dewasa kepada anak yang belum dewasa untuk mencapai tujuan, yaitu kedewasaan. ${ }^{3}$ Azyumardi Azra berpendapat bahwa pendidikan "merupakan suatu proses penyiapan generasi muda untuk menjalankan kehidupan dan memenuhi tujuan hidupnya secara lebih efektif dan efisien". ${ }^{4}$ Sedang dalam UU RI No. 20 Tahun 2003 disebutkan bahwa pendidikan adalah "usaha sadar dan terencana untuk mewujudkan suasana belajar dan proses pembelajaran agar peserta didik secara aktif mengembangkan potensi dirinya untuk memiliki kekuatan spiritual keagamaan, pengendalian diri, kepribadian, kecerdasan, akhlak mulia, serta keterampilan yang diperlukan dirinya, masyarakat, bangsa dan negara". ${ }^{5}$

Dari pengertian di atas dapat disimpulkan bahwa pendidikan adalah proses bimbingan yang dilakukan orang dewasa secara sadar terhadap anak untuk dapat hidup layak sesuai tuntutan zaman. Sebagai suatu proses bimbingan, pendidikan merupakan kegiatan yang dilakukan secara terencana dan sistematis. Pelakunya adalah seseorang atau suatu lembaga (institusi) yang dikenal dengan keluarga sebagai

\footnotetext{
${ }^{1}$ Depdikbud, Kamus Besar Bahasa Indonesia, Cet. III, Balai Pustaka, Jakarta, 1990, hal. 853. Ada 2 kata yang sering digunakan dalam dunia pendidikan yang hampir sama bentuknya, yaitu paedagogie yang berarti pendidikan dan paedagogiek yang berarti ilmu mendidik. Kata paedagoog (dari paedagogos) berarti seorang yang tugasnya membimbing anak di dalam pertumbuhannya ke arah berdiri sendiri dan bertanggung jawab. Lihat, Ngalim Purwanto, Ilmu Pendidikan-Teoritis dan Praktis, Remaka Karya, Bandung, 1985, hal. 1

${ }^{2}$ Abuddin Nata, Filsafat Pendidikan Islam, Gaya Media Pratama, Jakarta, 2005, hal. 5. "Education is the process of training the knowledge, skill, mind, character especially by formal schooling, teaching, and training". Lihat, Mc Rechnie Jean, I webster New Twintieth Century Distionary, William Collin Publisher, Ttp, 1980, hal. 57.

${ }^{3}$ Lihat, Burhanuddin Salam, Pengantar Pedagogik (Dasar-Dasar Ilmu Mendidik), Rineka Cipta, Jakarta, 1997, hal. 3-4.

${ }^{4}$ Azyumardi Azra, Pendidikan Islam, Tradisi dan Modernisasi Menuju Milenium Baru, Cet. II, Logos, Jakarta, 2000, hal. 3.

${ }^{5}$ Fokusmedia, Undang-Undang RI No. 20 Tahun 2003 tentang Sisdiknas beserta Penjelasannya, Fokusmedia, Bandung, 2003, hal. 3.
} 
pendidikan informal, sekolah atau madrasah sebagai lembaga pendidikan formal, dan majlis ta'lim serta kegiatan lainnya di masyarakat sebagai pendidikan non formal. Obyeknya adalah peserta didik yang memerlukan bimbingan atau pembinaan. Kegiatan ini dilaksanakan berdasarkan pada suatu tujuan (agar peserta didik secara aktif mengembangkan potensi dirinya untuk memiliki kekuatan spiritual keagamaan, pengendalian diri, kepribadian kecerdasan, akhlak mulia, serta keterampilan yang diperlukan dirinya, masyarakat, bangsa dan negara). Bimbingan atau pembinaan itu dilakukan dengan suatu cara tertentu dalam situasi dan lingkungan tertentu.

Unsur-unsur pendidikan dalam definisi di atas terdiri dari usaha (kegiatan) yang bersifat bimbingan dan dilakukan secara sadar, pendidik (pembimbing), anak didik, dasar dan tujuan, dan alat-alat yang digunakan dalama usaha itu. ${ }^{6}$ Dengan istilah lain, sebagai suatu sistem pendidikan memiliki unsur pelaku (organik) dan bukan pelaku (anorganik). Unsur pelaku adalah pendidik, peserta didik, dan unsur bukan pelaku berupa piranti keras (hardware) dan piranti lunak (soft-ware), seperti tujuan, sarana, dan lingkungan. ${ }^{7}$

Dengan demikian dapatlah dikatakan bahwa pendidikan sebagai sebuah sistem terdiri dari tujuan, metode, materi (kurikulum), pendidik, anak didik, alat pendidikan, dan lingkungan. Semua unsur ini saling berkaitan satu sama lain.

Pendidikan saat ini menghadapi berbagai tantangan, antar lain bisa dilihat dari karakter anak. Karakter anak zaman now semakin nyeleneh dan semaunya sendiri. Anak-anak cenderung egois, tidak suka bekerja sama. Hal ini disebabkan seringnya mereka lebih suka bermain game lewat ponsel android daripada permainan tradisional yang mengajarkan perilaku untuk bekerjasama. Fenomena ini tidak bisa dipungkiri, baik itu di kota maupun di pelosok desa sekalipun. Karakter anak pada sebagian generasi millenial memprihatinkan. Mereka kadang tidak menghargai orangtua maupun gurunya. Bahkan dari mereka juga terkadang terjebak pada dunia kriminal

\footnotetext{
${ }^{6}$ Ahmad D. Marimba, Filsafat Pendidikan Islam, hal. 19.

${ }^{7}$ Lihat, Suwito, Filsafat Pendidikan Akhlak Ibnu Miskawaih, Belukar, Yogyakarta, 2004, hal. 49.
} 
dan narkoba. Generasi millenial dalam minat belajar juga sebagian besar mengalami kemunduran. ${ }^{8}$

Di era millennial, kecenderungan dunia pendidikan antara lain: berkembangnya model belajar jarak jauh (Distance Learning), mudahnya menyelenggarakan pendidikan terbuka, sharing resource bersama antar lembaga pendidikan, perpustakaan dan instrument pendidikan lainnya (guru, dosen, laboratorium) berubah fungsi menjadi sumber informasi daripada sekedar rak buku. Lembaga pendidikan akan menghadapi sebuah perubahan yang signifikan akibat proses digital ini. Ini menjadi sebuah peluang dan cara untuk meningkatkan kualitas pendidikan sekaligus tantangan bagi dunia pendidikan di Indonesia. ${ }^{9}$

Pada era millenial, manusia mulai meninggalkan cara-cara konvensional dalam menjalani kehidupan, digantikan dengan trend dan gaya hidup yang lebih fresh and youth, atau yang biasa dikenal dengan istilah "kekinian". Seorang aktivisi HMI, Muhammad Ridal, dalam bukunya yang berjudul "HMI Millenial" mengungkapkan bahwa 33\% masyarakat Indonesia saat ini merupakan generasi millenial. Menurut Ridal, era millenial umumnya didominasi oleh orang-orang kelahiran tahun 1980 sampai tahun 2000an, dan berusia 15-34 tahun. Usia ini, tentu saja, merupakan usia dimana individu masih berstatus sebagai pelajar di sekolah. ${ }^{10}$

Dalam artikel ini akan dipaparkan bagaimana pendidik melakukan upaya mendidik generasi sekarang dengan baik dengan judul "Tantangan Pendidik di Era Millennial"

${ }^{8}$ https://student.cnnindonesia.com/edukasi/20171219114411-445-263408/pendidikan-dandigitalisasi -di-era-milenial/, Diakses pada tanggal 18 Oktober 2018. Dan http://radarsemarang.com/ 2018/08/02/ tantangan-era-millenial-dalam-dunia-pendidikan/. Dikutip pada tanggal 18 Oktober 2018

${ }^{9}$ https://student.cnnindonesia.com/edukasi/20171219114411-445-263408/pendidikan-dandigitalisa-si-di-era-milenial/, Diakses pada tanggal 18 Oktober 2018

${ }^{10} \mathrm{https} / / / \mathrm{www}$. selasar.com/jurnal/42846/Guru-BK-Kekinian-Solusi-Masalah-Siswa-di-EraMillenial. Diakses tanggal 18 Oktober 2018. 


\section{METODE}

Artikel ini menggunakan metode kualitatif dengan pendekatan kepustakaan (library research) yang memusatkan pada perilaku siswa yang senang berselancar di dunia maya melalui android, gadget atau handphone canggih yang mereka miliki. Perilaku siswa ini ditandai oleh adanya kecendrungan lebih senang membaca melalui handphone ketimbang buku, senang mencari berbagai informasi sendiri tanpa melakukan recheck lebih dahulu, senang mencari teman melalui akun media sosial, dan terkesan individualis. Setelah data didapat kemudian dianalisis dengan menggunakan teori yang dianggap relevan.

\section{PEMBAHASAN}

A. Generasi Millennial.

"Millennial yang juga disebut dengan generasi $\mathrm{Y}$ adalah sekelompok orang yang lahir setelah Generasi $X$, yaitu orang yang lahir pada kisaran tahun 1980-2000 an. Ini berarti millenial adalah generasi muda yang berumur 17- 37 pada tahun ini,"11 Meskipun beberapa siswa millennial telah putus sekolah atau lulus di universitas dan memasuki dunia kerja, namun sebagian besar dari mereka masih berada di dalam sistem sekolah.

Siswa $^{12}$ yang hidup di era millenial menghabiskan 6,5 jam setiap hari untuk membaca media cetak, elektronik, digital, broadcast dan berita. Mereka mendengarkan dan merekam musik; melihat, membuat, dan mempublikasikan konten internet serta tidak ketinggalan menggunakan smartphone. Orang-orang muda pada era kekinian ini memiliki berbagai macam karakteristik. Mereka suka

\footnotetext{
${ }^{11}$ https://www.ump.ac.id/Berita-1188-Tantangan.Guru.di.Era.Milenial.html. Diakses tgl. 18 Oktober 2018.

${ }^{12}$ Ada tiga sebutan untuk pelajar, yaitu murid, anak didik, dan peserta didik. Istilah murid adalah khas pengaruh agama Islam. Istilah murid menunjukkan kepatuhan murid pada guru (mursyid)nya. Sebutan anak didik mengandung pengertian guru menyayangi murid seperti anaknya sendiri. Faktor kasih sayang salah satu kunci keberhasilan pendidikan. Sedang peserta didik menekankan pentingnya murid berpartisipasi dalam proses pembelajaran. (Lihat, Ahmad Tafsir, Filsafat Pendidikan Islami, Remaja Rosdakarya, Bandung, 2006, hal. 165)
} 
memegang kendali, tidak mau terikat dengan jadwal tambahan, dan mereka tidak terlalu suka duduk di ruang kelas untuk belajar atau di kantor untuk bekerja. Sebaliknya, mereka lebih suka menggunakan teknologi untuk belajar kapan saja, siang, atau malam, melakukan telekomunikasi dari mana saja dan mendefinisikan "keseimbangan" dengan cara masing-masing. Selain itu, di lingkungan berbasis proyek, generasi millenium menggunakan teknologi untuk menyelesaikan tugas dengan cara baru dan kreatif. Kebutuhan mereka akan metode alternatif untuk menyelesaikan tugas menghadirkan tantangan ketika menggunakan pengukuran tradisional untuk menentukan produktivitas. Mereka juga berorientasi pada kelompok dan sosial. Tanpa henti terekspose ke dunia melalui media, generasi milennial terus-menerus menjalin hubungan sosial. Secara pribadi, mereka melakukan perjalanan berkelompok, belanja, dan bermain bersama. Secara online, mereka mencari peluang untuk mengidentifikasi teman-teman dalam skala yang lebih kecil, bergabung dengan komunitas, dan bergaul dengan rekanrekan di seluruh dunia. ${ }^{13}$

Menurut M Faturohman, generasi millenial mempunyai tujuh sifat dan perilaku sebagai berikut: millenial lebih percaya informasi interaktif daripada informasi searah, millenial lebih memilih ponsel dibanding TV, millenial wajib punya media social, millenial kurang suka membaca secara konvensional, millenial lebih tahu teknologi dibanding orangtua mereka, millenial cenderung tidak loyal namun bekerja efektif, serta millenial mulai banyak melakukan transaksi secara cashless. $^{14}$

Generasi millenial juga berpengaruh sekali pada dunia pendidikan. Kecenderungan minat belajar yang serius mulai menurun drastis, karena millenial khususnya di Indonesia sudah kecanduan internet yang disalah

\footnotetext{
${ }^{13}$ https://www.ump.ac.id/Berita-1188-Tantangan.Guru.di.Era.Milenial.html. Diakses tgl. 18 Oktober 2018.

${ }^{14}$ http://radarsemarang.com/2018/08/02/tantangan-era-millenial-dalam-dunia-pendidikan/. Diakses pada tanggal 18 Oktober 2018
} 
gunakan, bukan semata untuk mencari informasi berkaitan dengan ilmu pengetahuan.

Generasi millenial cenderung beperilaku pragmatis dan instan. Karena itu, perlu disadari bersama bahwa dalam menyikapi masalah ini perlu dilakukan langkah-langkah konkrit, supaya tujuan dari Pendidikan Nasional tetap konsisten dengan mengikuti era millenial ini.

B. Professionalisme pendidik (guru)

Guru $^{15}$ adalah "pendidik yang memberikan pelajaran kepada murid". ${ }^{16}$ Menurut Zakiah Daradjat, guru adalah "pendidik profesional, karena secara implisit ia telah merelakan dirinya menerima dan memikul sebagian tanggung jawab pendidikan yang dipindahkan para orang tua. Kata guru ${ }^{17}$ sebenarnya bukan saja mengandung

${ }^{15}$ Ahmad Tafsir, Ilmu Pendidikan dalam Perspektif Islam, Remaja Rosdakarya, Bandung, 1982, hal. 72. Pengertian guru lebih luas dikemukakan oleh M. Ngalim Purwanto, yaitu "guru adalah semua orang yang pernah memberikan suatu ilmu atau kepandaian yang tertentu kepada seseorang atau sekelompok orang". M. Ngalim Purwanto, Ilmu Pendidikan Teoritis dan Praktis, Remaja Karya, Bandung, 1985, hal. 169.

${ }^{16}$ Ahmad Tafsir, Ilmu Pendidikan dalam Perspektif Islam, Remaja Rosdakarya, Bandung, 1982, hal. 72. Pengertian guru lebih luas dikemukakan oleh M. Ngalim Purwanto, yaitu "guru adalah semua orang yang pernah memberikan suatu ilmu atau kepandaian yang tertentu kepada seseorang atau sekelompok orang". M. Ngalim Purwanto, Ilmu Pendidikan Teoritis dan Praktis, Remaja Karya, Bandung, 1985, hal. 169.

${ }^{17}$ Rasulullah SAW bersabda:

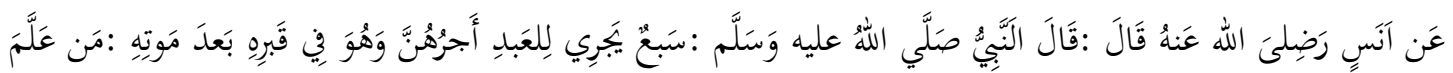

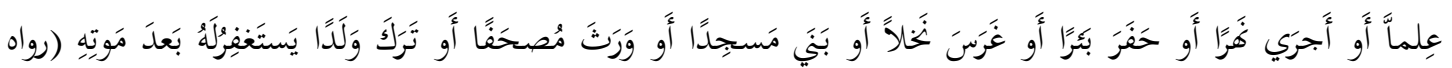

"Dari Anas r.a berkata: Nabi saw. Bersabda: Ada tujuh hal yang pahalanya mengalir pada seorang hamba semenjak dia didalam kubur setelah kematianya, yaitu: Orang yang mengajarkan sesuatu ilmu, atau mengalirkan sungai (memberikan pengairan), atau menggali sumur, atau menanam pohon kurma, atau membangun masjid, atau mewariskan mushaf, atau meninggalkan anak yang memohonkan ampun kepadanya setelah kematianya. 
arti pengajar melainkan juga pendidik baik di dalam sekolah maupun luar sekolah". ${ }^{18}$ Sebagai bagian dari komponen pendidikan, seorang guru memiliki peran vital untuk keberhasilan dalam sebuah pendidikan. Meskipun dalam pembelajaran sekarang seorang guru lebih banyak berperan sebagai motivator, tetapi keberadaannya tidak dapat digantikan oleh media pendidikan lainnya, meski alat itu sangat canggih. Oleh karena itu, guru adalah bagian dari unsur pendidikan yang sangat menentukan. ${ }^{19}$

Profesi adalah pekerjaan yang dilakukan seseorang yang ahli atas dasar pengakuan dari orang lain yang disertai bukti nyata bahwa orang yang melakukan pekerjaan tersebut benar-benar mampu melaksanakan pekerjaan yang memang sudah menjadi keahliannya. ${ }^{20}$ Profesi juga berarti suatu pekerjaan yang mensyaratkan untuk dimilikinya kemampuan akademik dari pendidikan tinggi dengan penekanannya pada pekerjaan mental dan bukan pekerjaan manual. ${ }^{21}$ Jadi, profesi adalah pekerjaan, yaitu suatu kebiasaan yang dilakukan seseorang sehingga ia dapat hidup dari hasil keringatnya. ${ }^{22}$

Sebagai sebuah profesi, seorang guru wajib memiliki kualifikasi akademik, kompetensi, sertifikasi pendidik, sehat jasmani dan rohani, serta memiliki kemampuan untuk mewujudkan tujuan pendidikan nasional. ${ }^{23}$

\footnotetext{
${ }^{18}$ Zakiah Daradjat dkk, Ilmu Pendidikan Islam, Bumi Aksara dan Ditjen Binbaga Islam, Jakarta, 1990, hal. 39.

${ }^{19}$ Dalam interaksi antara pendidik dan peserta didik, guru (pendidik) memegang peranan kunci bagi berlangsungnya kegiatan pendidikan. Tanpa kelas, gedung, peralatan dan sebagainya, proses pendidikan masih dapat berjalan walaupun dalam keadaan darurat, tetapi tanpa guru proses pendidikan hampir tak mungkin dapat berjalan. Lihat, Nana Syaodih Sukmadinata, Pengembangan Kurikulum Teori dan Praktek, Remaja Rosdakarya, Bandung, 1997, hal. 203.

${ }^{20}$ Mursidin, Profesionalisme Guru Menurut al-Qur1an, Hadits dan Ahli Pendidikan, Sedaun, Jakarta, 2011, hal. 48

${ }^{21}$ Sudarwin Danim, Inovasi Pendidikan: Dalam Upaya Peningkatan Profesionalisme Tenaga Kependidikan, Pustaka Setia, Bandung, 2002, hal. 20

${ }^{22}$ Yadi Puwanto, Etika Profesi: Psikologi Profetik Perspektif Psikologi Islami, Cet. 1, Refika Aditama, Bandung, 2007, hal. 1

${ }^{23}$ Citra Umbara, Undang-Undang Republik Indonesia Nomor 14 Tahun 2005 Tentang Guru dan Dosen, Bab IV, Pasal 8, Citra Umbara, Bandung, 2006, hal. 8 . Ini diisyaratkan Allah dalam surah al-Najm/53: 5-6
}

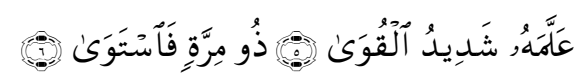


Kualifikasi akademik seorang guru adalah S1 atau diploma IV. Kompetensi yang harus dimiliki seorang guru adalah kompetensi pedagogik, kompetensi kepribadian, kompetensi social dan kompetensi professional yang diperoleh melalui pendidikan profesi. ${ }^{24}$ Masing-masing kompetensi tersebut bila dirinci sebagai berikut:

1. Memiliki kepribadian sebagai pendidik dengan sub kompetensi
a. Memiliki kepribadian mantap dan stabil
b. Memiliki kepribadian dewasa
c. Memiliki kepribadian arif
d. Memiliki kepribadian yang berwibawa
e. Memiliki akhlak mulia dan dapat menjadi teladan

2. Memiliki kompetensi pedagogik dengan sub kompetensi
a. Memahami peserta didik
b. Merancang pembelajaran
c. Melaksanakan pembelajaran
d. Evaluasi hasil belajar
e. Pengembangan peserta didik

3. Memiliki kompetensi profesional sebagai pendidik dengan sub kompetensi:

a. Menguasai bidang studi secara luas \& mendalam

b. Memahami materi ajar yang ada dalam kurikulum sekolah

c. Memahami struktur, konsep, dan metode keilmuan yang menaungi/koheren materi ajar

d. Memahami hubungan konsep antar mata-pelajaran terkait

e. Menerapkan konsep-konsep keilmuan dalam kehidupan sehari-hari

f. Berkomunikasi secara efektif dengan masyarakat

4. Memiliki kompetensi sosial sebagai pendidik. Sub Kompetensi yaitu kemampuan berkomunikasi secara efektif:

a. Berkomunikasi secara efektif dengan peserta didik, sejawat, dan orang tua/wali

b. Bergaul secara efektif

c. Bekerja sama secara efektif dengan peserta didik, sejawat, orang tua/

Yang diajarkan kepadanya oleh (Jibril) yang sangat kuat. Yang mempunyai akal yang cerdas; dan (Jibril itu) menampakkan diri dengan rupa yang asli. Ini memberikan isyarat bahwa seorang pendidikan harus berpenampilan prima. Penampilan prima itu dapat dilihat dari: 1). Kecerdasan yang dia miliki. 2). Keluasan wawasan keilmuannya. 3). Ketinggian akhlak yang tampak dalam perilaku. 3). Penampilan yang meyakinkan, yang mengundang kekaguman dan simpatik anak didik.

${ }^{24}$ Citra Umbara, Undang-Undang Republik Indonesia Nomor 14 Tahun 2005 Tentang Guru dan Dosen, Bab IV, Pasal 10, hal. 9. 
wali, dan masyarakat. ${ }^{25}$

Etos kerja yang baik bagi seorang guru ada 4 parameter, yaitu:

1. Mempunyai pandangan bahwa kerja merupakan hal yang mulia, dan ia akan sangat menghargai pekerjaannya.

2. mempunyai motivasi dan keinginan untuk menyelesaikan pekerjaan dengan baik pula.

3. Adanya upaya-upaya untuk menyempurnakan pekerjaannya agar lebih produktif.

4. Adanya kebanggaan terhadap pekerjaan yang menjadi profesinya. ${ }^{26}$

C. Tantang pendidik di Era Millenial.

1. Karakteristik generasi millenial

Generasi millennial memiliki beberapa karakteristik, yaitu:

1. Millennial tidak percaya lagi kepada distribusi informasi yang bersifat satu arah. Mereka lebih percaya kepada konten dan informasi yang dibuat oleh perorangan. Dalam hal pola konsumsi, banyak dari mereka memutuskan untuk membeli produk setelah melihat review atau testimoni yang dilakukan oleh orang lain di internet. Mereka juga tak segan-segan membagikan pengalaman buruk mereka terhadap suatu merek.

2. Millennial lebih memilih ponsel dibanding TV. Televisi bukanlah prioritas generasi millennial untuk mendapatkan informasi atau melihat iklan. Generasi millennial lebih suka mendapat informasi dari ponselnya, dengan mencarinya ke Google atau perbincangan pada forum-forum yang mereka ikuti.

3. Millennial wajib punya media sosial. Komunikasi di antara generasi millennial sangatlah lancar. Komunikasi itu tidak selalu terjadi dengan tatap muka. Banyak dari mereka melakukan semua komunikasinya melalui text messaging atau juga chatting di dunia maya, dengan membuat akun yang berisikan profil dirinya, seperti Twitter, Facebook, hingga Line. Akun media sosial juga dapat dijadikan

\footnotetext{
${ }^{25}$ Lihat, hal. 5, Martinis Yamin, Profesionalisasi Guru dan Implementasi KTSP, Gaung Persada Press, Jakarta, 2007

${ }^{26}$ Lihat, Mursidin, Profesionalisme Guru Menurut al-Qur1an, Hadits dan Ahli Pendidikan, hal. 94
} 
tempat untuk aktualisasi diri dan ekspresi. Hampir semua generasi millennial dipastikan memiliki akun media sosial sebagai tempat berkomunikasi dan berekspresi.

4. Millennial kurang suka membaca secara konvensional. Bagi generasi ini, tulisan dinilai memusingkan dan membosankan. Generasi millennial bisa dibilang lebih menyukai melihat gambar, apalagi jika menarik dan berwarna. Hobi membaca buku masih tetap ada. Mereka lebih memilih membaca buku online (e-book) untuk tidak perlu repot membawa buku. Sekarang ini, sudah banyak penerbit yang menyediakan format e-book untuk dijual, agar pembaca dapat membaca dalam ponsel pintarnya.

5. Millennial lebih tahu teknologi dibanding orangtua mereka. Kini semua serba digital dan online. Generasi ini melihat dunia tidak secara langsung, yaitu dengan berselancar di dunia maya. Generasi millennial adalah generasi yang sangat modern, lebih daripada orang tua mereka. Mereka sering mengajarkan teknologi pada kalangan orangtua.

6. Millennial cenderung tidak loyal namun bekerja efektif. Mereka juga tidak loyal terhadap suatu pekerjaan atau perusahaan, namun lebih loyal terhadap merek. Millennial hidup di era informasi yang menjadikan mereka tumbuh cerdas. Banyak perusahaan yang mengalami kenaikan pendapatan karena memperkerjakan millennial.

7. Millennial mulai banyak melakukan transaksi secara cashless. Dengan kecanggihan teknologi yang semakin maju ini, generasi millennial pun mulai melakukan transaksi pembelian yang sudah tidak menggunakan uang tunai lagi alias cashless. Generasi ini lebih suka membawa kartu, karena semua pembelian bisa dibayar menggunakan kartu, sehingga lebih praktis, hanya perlu gesek atau tapping. $^{27}$

${ }^{27}$ Miftah Mucharomah, "Kisah sebagai Metode Pembentukan dan Pembinaan Akhlak dalam Perspektif Al-Qur'an"dalam Jurnal Edukasia Islamika: Volume 2, Nomor 2, Desember 2017/1438 PISSN : 2548-723X; E-ISSN : 2548-5822, hal. 204-207 


\section{Tantangan Guru}

Citra dan konsep tentang guru dalam masyarakat kontemporer sangat jauh berbeda dengan konsep masa lampau. Guru masa dahulu berarti orang yang berilmu, yang arif dan bijaksana. ${ }^{28}$ Kini guru dilihat sebagai fungsionaris pendidikan yang bertugas mengajar atas dasar kualifikasi keilmuan dan akademis tertentu. Dengan tugas tersebut, guru memperoleh imbalan materi dari negara atau pihak pengelola pendidikan. Dengan demikian, faktor terpenting dalam profesi guru adalah kualifikasi keilmuan dan akademis. Sementara kearifan dan kebijaksanaan yang merupakan sikap dan tingkah laku moral tidak lagi signifikan. Dalam konsep klasik, faktor moral berada di atas kualifikasi keguruan. ${ }^{29}$

Berdasarkan penelitian bahwa mayoritas millennial mendapatkan berita bersumber dari media sosial seperti facebook dan twitter, dimana kredibilitas sumber berita sangat sulit untuk diukur. Penelitian menunjukkan bahwa generasi millennial cenderung malas untuk memvalidasi kebenaran berita yang mereka terima dan cenderung menerima informasi hanya dari satu sumber, yaitu media social. Inilah kondisi peserta didik saat ini, yang lebih memanfaatkan dan percaya dengan media sosial dalam kegiatannya sehari-hari. ${ }^{30}$

\footnotetext{
${ }^{28}$ Rasulullah SAW bersabda:

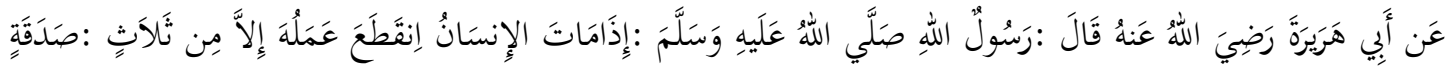

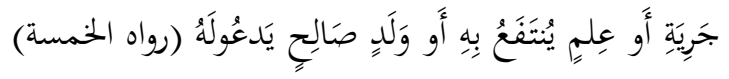

"Dari Abu Hurairah r.a berkata Rosulullah saw. Bersabda: Jika seorang manusia mati maka terputusnya amalnya kecuali tiga perkara yaitu: Sedekah (yang masih mengalirkan manfaat), ilmu yang bermanfaat, dan anak sholeh yang mendoakan kepadanya"

${ }^{29}$ Miftah Mucharomah, "Kisah sebagai Metode Pembentukan dan Pembinaan Akhlak dalam Perspektif Al-Qur'an"dalam Jurnal Edukasia Islamika: Volume 2, Nomor 2, Desember 2017/1438 PISSN : 2548-723X; E-ISSN : 2548-5822, hal. 202-203.

${ }^{30}$ Miftah Mucharomah, "Kisah sebagai Metode Pembentukan dan Pembinaan Akhlak dalam Perspektif Al-Qur'an”, hal. 203 
Tantangan guru di era milenial sangat berat dibanding guru-guru di era terdahulu. Selain menguasai aspek materi keilmuan yang di ajarkan. Guru dituntut memahami teknologi dan selalu menjadi pribadi yang kreatif dan inovatif. Guru harus menjadi role model bagi siswa di generasi millennial, agar siswa memahami batasanbatasan teknologi, sehingga terhindar dari pemamfaatan yang salah dalam menggunakan teknologi.

Tantangan bagi guru tidak berhenti disini, generasi millennial bukan generasi yang bisa dipaksa-paksa, contoh dengan melarang siswa membawa handphone. Guru di era sekarang harus lebih terbuka dengan pemikiran-pemikiran baru. Guru dituntut mendidik siswa sesuai dengan zamanya. Selama tidak bertentangan dengan normanorma yang ada tentu hadirnya teknologi tidak perlu dipermasalahkan.

Pendekatan persuasif baiknya lebih prioritas dilakukan ketimbang melakukan kebijakan-kebijakan yang terkesan otoriter maupun memaksakan kehendak. Guru bisa memberikan pengertian kepada siswa melalui kebijakan-kebijakan konkret dengan memanfaatkan teknologi dalam pembelajaran, seperti e-learning, atau menggunakan sosial media dll. Siswa justru mendapatkan edukasi bahwa teknologi ketika dimanfaatkan dengan baik justru memiliki dampak yang positif.

Secara umum, guru hendaknya memahami perubahan sosial yang ada di era sekarang. Dia tidak berhenti belajar mengenai hal-hal baru. Tantangan global di era sekarang juga beda dengan tantangan global di era dahulu. Apapun langkah dan metode yang dilakukan di sekolah pastinya bertujuan membentuk karakter dan menyiapkan SDM yang berkualitas di Indonesia. Masa depan Indonesia ada didalam ruang kelas yang kita ajar. ${ }^{31}$

Tantangan lain pendidikan di era millennial sekarang ini adalah informasi datang lebih cepat, massif dan meluas, sehingga tidak bisa diatasi dengan sekedar pergantian kurikulum. Berapa kali pergantian kurikulum tidak akan pernah mampu mengejar percepatan informasi yang ada. Karena itu, pendekatan guru dan murid

\footnotetext{
${ }^{31}$ https://dhinarmahardikaa.wordpress.com/2017/11/02/tantangan-menjadi-guru-di-eramilenial/. Diakses pada tanggal 18 Oktober 2018.
} 
dalam berinteraksi akan lebih penting. Perlu keteladanan, membangun kehendak, dan menguatkan - dengan bekal ilmu pengetahuan tentunya - sehingga anak didiknya mampu mengatasi tantangan hidupnya.

Tantangan terakhir bagi seorang guru adalah adanya empat keterampilan yang diberikan kepada siswa sejak dini, yaitu melahirkan pemikir, melahirkan komunikator, melahirkan kolaborator, dan melahirkan penemu atau pencipta. ${ }^{32}$

\section{Upaya yang dilakukan}

Ada beberapa upaya yang harus dilakukan oleh seorang guru menghadapi tantang dalam mendidik generasi millennial ini.

a. Guru-guru yang lahir pada era revolusi industri ketiga harus mengajar mereka yang lahir pada era berikutnya. Tidak bisa tidak, setiap guru wajib mengikuti perkembangan teknologi. Guru tidak boleh lagi gagap teknologi. Komputer dan gawai harus sudah menjadi keseharian para guru. Media sosial dan berbagai sumber informasi maupun sosialisasi juga harus dipahami para guru, sehingga dalam menjalankan profesinya guru akan kaya dengan materi maupun metode pembelajaran. Siswa pun tidak akan menganggap remeh guru.

b. Selain menguasai perkembangan teknologi, guru dituntut juga memahami kecenderungan yang terjadi terkait perubahan teknologi. ${ }^{33}$. Dengan mengikuti perkembangan hasil kemajuan teknologi, guru bakal mampu memberikan sudut

\footnotetext{
${ }^{32}$ Untuk melahirkan pemikir, siswa dilatih menyampaikan gagasan aktual, seperti kemacetan, banjir, tawuran. Untuk melahirkan komunikator, siswa dilatih menyampai ide secara lisan dengan baik. Untuk melahirkan kolaborator, siswa dikelompokan berdasarkan ragam kecerdasannya. Untuk melahirkan penemu, siswa dilatih menjadi inovator. Jejen Musfah, Analisis Kebijakan Pendidikan, Prenadamedia, Jakarta, 2016, hal. 84-86

${ }^{33}$ Revolusi industri pertama ditandai kemunculan mesin menggantikan tenaga manusia dan hewan. Generasi kedua ditandai dengan kemunculan pembangkit tenaga listrik dan motor pembakaran, hingga muncullah pesawat telepon, mobil, pesawat terbang dan sebagainya. Generasi ketiga ditandai dengan kemunculan teknologi digital dan internet. Pada revolusi industri generasi keempat ditandai dengan kemunculan superkomputer, robot pintar, rekayasa genetika dan perkembangan neuroteknologi yang memungkinkan manusia untuk lebih mengoptimalkan fungsi otak. Muncul pola-pola baru ketika disruptif teknologi hadir begitu cepat dan mengancam keberadaan pola lama
} 
pandang, alternatif, bahkan solusi kepada para peserta didik. Di sinilah peran guru yang tidak tergantikan oleh teknologi. ${ }^{34}$

c. Dalam pembelajaran, guru harus dapat menguatkan kemampuan olah pikir, olah rasa, olah hati, dan olah ragawi setiap anak. Hal itu penting agar mereka mampu memaknai, mengolah, menginterpretasi, menyaring berbagai informasi yang ada di sekitar.

d. Guru harus memberikan pembelajaran yang relevan dengan siswa. Belajar menjadi lebih berarti ketika mereka memahami aplikasi praktis informasi yang mereka terima. Konten harus spesifik, ringkas, dan cepat. Generasi millenal haus informasi dan akan mencarinya sendiri jika guru tidak menyajikan apa yang mereka anggap relevan. Karena begitu banyak informasi yang selalu tersedia, mereka tidak merasa perlu belajar setiap hal segera. Sebaliknya, mereka ingin diajari bagaimana dan di mana mereka dapat menemukan apa yang mereka butuhkan.

d. Dalam konteks era digital tentu pendidikan karakter sangat penting. Mengingat, internet adalah belantara yang liar, di mana konten-konten informasi yang positif dan negatif bercampur jadi satu. Hanya fondasi moral yang kuat di dalam diri, dalam arti bisa membedakan mana yang baik dan buruklah yang bisa menjamin masa depan generasi muda Indonesia tetep cerah. Oleh karena itu, seorang guru harus menjaga karakter kebangsaan yang potensial terkikis oleh berbagai ideologi mulai dari hedonisme hingga radikalisme yang tidak sesuai dengan Pancasila dan Negara Kesatuan Republik Indonesia (NKRI).

e. Di era globalisasi ini, pendidikan harus melakukan reformasi dan inovasi dalam proses belajar mengajar secara terus menerus. Untuk itu, diperlukan dukungan empirik yang dihasilkan oleh kegiatan penelitian. Oleh karena itu, guru harus paham penelitian. ${ }^{35}$

\footnotetext{
${ }^{34}$ https://dhinarmahardikaa.wordpress.com/2017/11/02/tantangan-menjadi-guru-di-eramilenial/. Di-akses pada tanggal 18 Oktober 2018.

${ }^{35}$ Suyanto dan Djihad Hisyam, Refleksi dan Reformasi Pendidikan di Indonesia Memasuki Milenium III, Adicita Karya Nusa, Yogyakarta, 2000, hal. 35
} 


\section{KESIMPULAN}

Di era globalisasi dan informasi ini, guru mendapatkan tantangan berupa perilaku siswa yang senang berselancar di dunia maya melalui android, gadget atau handphone canggih yang mereka miliki. Perilaku siswa ini ditandai oleh adanya kecendrungan lebih senang membaca melalui handphone ketimbang buku, senang mencari berbagai informasi sendiri tanpa melakukan recheck lebih dahulu, senang mencari teman melalui akun media sosial, dan terkesan individualis.

Untuk itu, guru dalam pembelajaran harus mampu memanfaatkan Teknologi Informasi, menggunakan metode yang menyenangkan, memperkaya keilmuan dengan berbagai sumber bahan bacaan, dan mampu melakukan penelitian.

Demikian uraian yang berkaitan dengan tantangan pendidik di era Millennial dan upaya yang dilakukan untuk mencari solusi terhadap tantangan yang dihadapi guru. 


\section{DAFTAR PUSTAKA}

Azra, A. (2000). Pendidikan Islam, Tradisi dan Modernisasi Menuju Millenium Baru, Cet II. Jakarta: Logos.

D.Marimba, A. (n.d.). Filsafat Pendidikan Islam.

Danim, S. (2002). Inovasi Pendidikan: Dalam Upaya Peningkatan Profesionalisme Tenaga Kependidikan. Bandung: Pustaka Setia.

Depdikbud. (1990). Kamus Besar Bahasa Indonesia, Cet. III. In N. Purwanto, Ilmu Pendidikan-Teoritis dan Praktis (p. 1). Jakarta: Balai Pustaka.

dkk, Z. D. (1990). Ilmu Pendidikan Islam. Jakarta: Bumi Aksara dan Ditjen Binbaga Islam.

Fokusmedia. (2003). Undang-undang RI No. 20 Tahun 2003 tentang Sisdiknas beserta Penjelesannya. Bandung: Fokusmedia.

Indonesia, C. (2018, Oct 18). Pendidikan dan Digitalisasi di Era Milenial. Retrieved from CNN Indonesia: https://student.cnnindonesia.com/edukasi/20171219114411-445-

263408/pendidikan-dan-digitalisasi -di-era-milenial

Lestari, R. (2018, Apr 3). Guru BK Kekinian: Solusi Masalah Siswa di Era Millenial. Retrieved from Selasar: https://www.selasar.com/jurnal/42846/Guru-BKKekinian-Solusi-Masalah-Siswa-di-Era-Millenial

Mahardika, D. (2018, Oct 18). Tantangan Menjadi GUru di Era Milenial. Retrieved from Dhinar For Indonesia: https://dhinarmahardikaa.wordpress.com/2017/11/02/tantangan-menjadi-gurudi-era-milenial/

Mucharomah, M. (2017). Kisah sebagai Metode Pembentukan dan Pembinaan AKhlak dalam Perspektif al-Qur'an. Jurnal Edukasia Islamika, 204-207.

Mursidin. (2011). Profesionalisme Guru Menurut al-Qur'an, Hadits dan Ahli Pendidikan. Jakarta: Sedaun.

Musfah, J. (2016). Analis Kebijakan Pendidikan. Jakarta: Prenadamedia. 
Nata, A. (2005). Filsafat Pendidikan Islam. Jakarta: Gaya Media Pratama.

Purwanto, M. N. (1985). Ilmu Pendidikan Teoritis dan Praktis. Bandung: Remaja Rosdakarya.

Purwekerto, U. M. (2018, Aug 27). Tantangan Guru di Era Milenial. Retrieved from Universitas Muhammadiyah Purwekerto: https://www.ump.ac.id/Berita-1188Tantangan.Guru.di.Era.Milenial.html

Puwanto, Y. (2007). Etika Profesi: Psikologi Profetik Perspektif Psikologi Islami, Cet. I. Bandung: Refika Aditama.

Salam, B. (1997). Pengantar Pedagogik (Dasar-dasar Ilmu Mendidik). Jakarta: Rineka Cipta.

Semarang, R. (2018, Oct 18). Tantangan Era Milenial dalam Dunia Pendidikan. Retrieved from Radar Semarang: http://radarsemarang.com/ 2018/08/02/ tantangan-era-millenial-dalam-dunia-pendidikan/

Sukmadinata, N. S. (1997). Pengembangan Kurikulum Teori dan Praktek. 1997: Remaja Rosdakarya.

Suwito. (2004). Filsafat Pendidikan Akhlak Ibnu Miskawaih. Yogyakarta: Belukar.

Suyanto, \& Hisyam, D. (2000). Refleksi dan Reformasi Pendidikan di Indoensia Memasuki Milenium III. Yogyakarta: Adicita Karya Nusa.

Tafsir, A. (1982). Ilmu Pendidikan dalam Perspektif Islam. Bandung: Remaja Rosdakarya.

Umbara, C. (2005). Undang-undang Republik Indonesia Nomor 14 Tahun 2005 tentang Guru dan Dosen Bab IV Pasal 10.

Umbara, C. (2006). Undang-undang Republik Indonesia Nomor 14 Tahun 2005 Tentang Guru dan Dosen Bab IV, Pasal *. Bandung.

Yamin, M. (2007). Profesionalisasi Guru dan Implementasi KTSP. Jakarta: Gaung Persada Press. 